\title{
Ways to Survive: Child Labor among Internally Displaced Children in Khartoum-Sudan
}

\author{
Azza 0. Abdelmoneium \\ Doha International Family Institute/Qatar Foundation, Doha, Qatar \\ Email: abdelmoneium@yahoo.com
}

How to cite this paper: Abdelmoneium, A.O. (2017) Ways to Survive: Child Labor among Internally Displaced Children in Khartoum-Sudan. Open Journal of Social Sciences, 5, 53-62.

https://doi.org/10.4236/jss.2017.59004

Received: August 8, 2017

Accepted: August 29, 2017

Published: September 1, 2017

Copyright $\odot 2017$ by author and Scientific Research Publishing Inc. This work is licensed under the Creative Commons Attribution International License (CC BY 4.0).

http://creativecommons.org/licenses/by/4.0/

(c) (i) Open Access

\begin{abstract}
Sudan has undergone civil war and natural disasters since 1980s until today. This has led to internally displaced people to Khartoum the capital. The majority of the internally displaced people are women and children. Access to health, educational facilities, employment and shelter is minimal or lacking. Men, women and children perform and engage in different types of child labor as a source of income generating activities. The purpose of this paper is to explore the different forms of income generating activities that displaced children perform as a source of income for them which can be of risk to their lives. Qualitative methodology used through open-ended unstructured interviews with the children. In this paper, I argue that if the state has provided a secure and protective environment for the displaced children with their basic needs in health, shelter, food and education, it would have led to better living conditions with minimal risk to their life and stable family relations. I will present case studies of displaced children under 18 years and their experiences in labor and the impact and challenges they face in producing income to support themselves and their families.
\end{abstract}

\section{Keywords}

Child Labor, Displaced, Income Generation, Rights, Gender, Street Children

\section{Introduction}

Sudan has a population of 39.1 million, increasing at a rate of $2.64 \%$ [1]. The population of Khartoum in 2015 was 5129; half of these are Internally Displaced Persons (IDP) from Darfur, South Sudan, Nuba Mountains, South Kordofan and Blue Nile residing in four main camps and 30 official squatter's areas [2]. An estimated 4.367 million people have been displaced; half of them are living in Khartoum (World Fact Book, 2015: 12, [3] [4]). 
Not only the civil war, but also natural disasters such as famine, drought and floods in the mid-1980s and 1990s, on-going conflicts in Darfur, South Kordofan and Blue Nile States, the South Sudan civil war contributed to the internal displacement of persons, bringing them to Khartoum and other cities in Sudan.

Internally displaced people are defined as "persons or groups of persons who have been forced or obliged to flee or to leave their homes or places of habitual residence, in particular as a result of or in order to avoid the effects of armed conflict, situations of generalized violence, violations of human rights, or natural or human-made disasters and who have not crossed an internationally recognized State border" [5]. The majority of the internally displaced people are women and children. The IDPs live in poor conditions with their basic needs largely unmet. Access to health and educational facilities, to income sources, employment, to adequate shelter and clean environment is minimal or lacking. Income generating activities are the primary concern for all the displaced. Most of the problem concern money for school fees, health treatment, food, clothing etc. The jobs are limited and the type of employment is normally unskilled labor. The significance and reason for this article is to examine why and displaced children are engaged in income generating activities to survive in the camps, and what are the types of income generating activities the children practice. The article will also examine the reason for engaging in labor and the impact of child labor on the children.

To survive in these conditions, men, women and children perform and engage in different types of income generating activities. The gender role and responsibilities for each member in the family differs in producing income to support the family. For example, the men usually engage in driving, laboring, construction, while the women in washing clothes, selling food, domestic work which are all activities that endanger the life of the displaced. Most of the women and men have to stay away from their children to provide them with income. This distorted the family.

Most importantly are the children who are engaged in many risky activities and income generating activities. To secure income, internally displaced children can live in the street as a source of income and engage in any activity to their families and named "street children". Other children are engaged in child labor activities such as begging, stealing, cleaning shoes, car washing which are all activities that are of danger to them.

Due to the poor condition in the camps, the children below age 18 are engaged in hazardous and dangerous activities to generate income to support themselves and/or their families. Child labor laws to protect children in Sudan exist but they are not enforced. The 1997 labor law in Sudan labor implies that children not to be employed in risky and harmful jobs. This in practice falls short. The law specifies that children under the age of 18 are to be protected from engaging in hazardous employment that can affect their health, education, physical, mental, or social development, but in Sudan children are legally employed from the age of 
16 and this is likely to have implications on their health, education, child development and family relations [6] [7]. This is in contradiction to the Convention on the Rights of the Child and to the International Labor Organization laws and legislations.

Child labor has an impact on child development and behavior. This might lead to family instability, aggressive and depressive family relations. In this paper, I argue that if the state has provided the displaced children with their basic needs in health, shelter, food and education it would have led to better living conditions. In addition, to minimal risk to their life with no need for engagement in income generating activities, which puts their lives in risk challenges.

\section{Methodology}

Qualitative methodology utilized to give more in-depth information and to hear the experiences of the children. This empirical data was mostly part of $\mathrm{PhD}$ dissertation conduced on the rights of internally displaced children and non-governmental organizations in Sudan. The method of data collection included in-depth interviews, focused group discussions, participant observation with the children and their family members. The interviews conducted with children from age 10 - 18 years. A sample of 129 displaced children from the four main camps in Khartoum. Empirical data was collected from 2005-2013. Recent data from secondary sources of reports and research done on displaced families and children in Sudan.

\section{Situation of Internally Displaced Children in the Camps in Khartoum}

Khartoum is the most affected state as it is the principal recipient of increasing numbers of displaced persons who have been arriving at a growing rate, from 14 per cent in 1956 to 42 per cent of the population in 1993. Women estimated at one-third and children under five constitute nearly 20 per cent of the IDP population in Khartoum, along with a significant number of old men and only a minority of young men capable of work. The average household consists of six to seven persons [8]. Approximately 15 per cent originate from Darfur, and the rest are from South Sudan, Blue Nile and South Kordofan (Lyytinen, 2009).

IDPs struggle to meet their basic needs of food, shelter, health and education. Living conditions are harsh, as they lack education and skills in a land with cultural and religious differences. It is challenging to make a living; with the fear of relocation and no consistent income, some forced into criminal activities ranging from petty thefts, bootlegging, and extortion to violent crimes [9].

In the hard life of displaced children, education is an important aspect. Their ambition is to finish school in order to raise their standard of living. Education, they said, enables a person to gain more confidence, self-reliance and self-esteem. However, the facilities and services for education are insufficient and discourage a positive attitude in children. That is why children need to seek employment to 
survive in the camp. Some of the factors, which led children to seek labor at an early age, are the poverty, the large family size, lack of interest in education, the death or absence of the breadwinner and the lack of social protection. These are some of the factors, which contributed to child labor, but also there are different types of children among the displaced who work. The next paragraphs will explain the types of displaced children and child labor.

\section{Types of Displaced Children and Child Labor}

Income and job insecurity is a major problem for the displaced families as a result; the children, women and men seek income-generating activities, which violate their rights, and endanger and risk their life. In particularly, children seek to generate income through different ways to survive which can cause dangerous and hazardous risk to their lives and in violation to their rights. Because many of the children spend large parts of the day on the street, they often caught under the umbrella term of "street children". Yet, the lives of these street children vary widely. Some grow up in a stable family that, although poor, is able to provide emotional support. Some as street children classify these because most of the times they are in the street in the city center looking for money. They return at the end of the day to their families. On the other end of the scale are the real street children who live and sleep in the street. I distinguish four categories of street children:

1) Children who go to school and work

The majority of displaced families need children's income, so the children take jobs in either the afternoon or evening.

\section{2) Children who work full time but live at home}

Those children dropped out of school and work the whole day on the street for example in shoe polishing or car cleaning.

3) Children living in the street but who have contact with their families

Children who live and work in the streets but they know their families and they have some contacts with them. Husna, a twelve-year old girl, left home after her stepfather abused her and her mother went to prison. She has contact with her mother but she does not want to return home. Some children also work in the street and support their other siblings, without living with them. Some NGOs are working to reunite those children with their families.

4) Children living in the street but who have no contact with their families

Those are children whose parents died or who are in conflict with their families. They live on the street and have no contact with their families. Those are real or full-time street children. The majority ended up on the street. This is because of bad relations with their families due to abusive parents and conflicts.

A common factor of these children is that they all work in the street to generate income, but the problem is that they risk their lives in the type of work they engage in and in the street. However, they have no choice other than engaging in income generating activities to secure income for food, health and education and 
support their families. The following paragraph will explain the type of income generating activities that the displaced perform and the struggle to secure.

\section{Income Generating Activities among Displaced Children}

Income generating activities are the primary source of income for all the displaced. Most of the problems concern money for school fees, health treatment, food, clothing, payment for licenses and so forth. This is because city life is a monetary economy, and the economic situation is poor. Job opportunities are extremely limited and few households are able to survive on one income. Individuals within a household often have more than two jobs and nearly all members of the household are involved in some form of income generation.

The jobs are limited and the only way that the displaced find jobs is through contacts. If one of his or her extended relatives is in a strong position, then he can help in finding a job or a place to live. This limits the opportunities for new displaced who come to the city, compared to long-term residents. It explains the importance of the extended family. Links between the displaced and the host community are limited, but some domestic workers get help from their employers in finding a job for their relatives. After establishing contact, one has to have proper legal documents: skills come last in the list.

Nevertheless, the type of employment is normally unskilled labor. The men usually engage in harvesting, driving a donkey cart, laboring, construction, driving, teaching, join the army or police, engage in trade or technical work, become guards or work in a factory. The women do domestic work, brewing, selling food, dying clothes, firewood collection, trade, sewing, basket making, washing clothes, nursing, handicrafts, and factory work. The boys drive donkey carts, sell cigarettes, polish shoes, work in factories or as casual labor, sell water and scavenge. The girls sell tea, help in the market, do domestic work and scavenge.

If we compare these wages with the cost of living, the struggle for the family to manage is evident. For a family with five children, expenditures on food, fuel and water would be 500 SDD per day that is 15,000 per month, equivalent to 60 dollars per month. Transport costs, especially in the distant camps like al-Salam, can reach 300 SDD per day equivalent to 12 cents. Taxes, clothes, health care, school fees and stationeries need to be paid. The minimum school fee is 5000 SDD per year equivalent to 20 dollars, but there are registration fees for the exams and this varies from one school to another. Books cost 500 SDD equivalent to 2 dollars per book and there are seven subjects or more in year. It is obvious that a family of five must struggle to live and needs several wage earners. The numbers in extended families are increasing and so are their dependency ratios. The Darfur war had displaced thousands of families. In Mayū camp in August 2004, more than 1200 families came to the camp to live with their relatives. Although many people in the household earn some money, the total household income is seldom above the minimum level. Few families eat more than two 
meals and the majority eat one meal per day. Some people get assistance from their relatives who work outside Sudan or other kin within the locality. People also borrow money and obtain items on credit from shopkeepers.

The opportunities for a secure monthly salary are decreasing, therefore, the greatest potential lies in trade, but to start a business one needs capital and equipment. Some non-profit organizations provide training in skills, for example carpentry or mechanics, but the children lack the equipment and capital even if they receive their training. Some children borrow a capital of 500 SDD from a relative or kin, buy toys, office supplies, fruits, vegetables, water, batteries, lamps, slippers or bags, and try to sell these in the streets. However, if they do not have a license to trade they arrest them.

Most of those involved in business said the increasing competition affect them. This is the result of a growing urban population and a deteriorating economy. Despite all this, the displaced children working in the street find ways and strategies to secure income. The following paragraph will explain the different strategies that children follow in the street and how they survive.

\section{Survival of Children in the Streets}

Children in the street live and survive through different strategies: collection of unused food from restaurants or wedding parties, begging, stealing, cleaning shoes, car washing and so on. Street children create groups and networks in the street and join for mutual support. Some form groups for car washing, while others engage in many activities including black market sale of alcohol and tobacco, dividing the profit amongst them. Street girls roam around begging, look after their children if they have any, and sometimes form relations with street boys and are partly depended upon them.

Strikingly, street children have their own language of communication.

Life in the street has advantages and disadvantages for the children. Some children think that the life on the street makes them more responsible and independent. The experience might even empower children, because there is no one to teach them, they learn by themselves the good and bad things in life. This depends on the background of the child. If the child is living in a supportive family, he/she uses the street as an opportunity to contribute and support his/her family. Children then feel self-reliant and responsible. If the child was abused and violated by his/her parents he/she uses the street as a way to escape, and here the child can easily be led into habits such as sniffing glue (sillision), drinking alcohol, smoking cigarettes and other harmful practices. One of the street children replied when I asked if he took sillision "Of course, to be part of the street you have to take it. It makes you strong and tough in the street and also to feel you belong in the street." Hawa, a ten-year old girl from the west of Sudan said:

I learned a lot from the street, I learned how to find food and work. I learned where to work in the street. I learned that no one is going to take care of me and I have to take care of myself. I used to work as a beggar from the age of five years 
and now I know the good and bad things in the street (27 May 2004, al-Salam camp).

The life in the street makes children learn different things, and forces them to face many difficulties in surviving. The street to them as Nieuwenhuys [10] said "is more than a place of work; it is where children enjoy friendships, engage in recreation by playing football and card, gossiping and obtain food and money to spend on themselves in a relatively easy way". However, street children also face harassment from the police. They are scared of the police who treat them roughly and take them to reformatories. In the reformatories, the treatment is harsh and there are few amenities. The older boys if caught by the police are send to the army. Street girls are vulnerable to harassment and the security guards in the reformatories, or the police sexually abuse them.

Some of the girls engage into prostitution for a living with all the consequences for a child's development. Despite the harsh life, some children get assistance from the public, for example, shop keepers allow them to sleep on their premises or give them food or sweets. The public despises street children. They regard them as delinquents and criminals, but still there are kind people who want to help them. Despite their survival strategies, child labor is considered a challenge to children and can cause health and development problems in the end.

\section{Challenges of Child Labor}

Studies revealed that child labor has a negative impact on the physiological and psychological levels of children. This might include specific concerns of child labor and its consequences on mental health. It was stated "one-third of the children of developing world are failing to complete even 4 years of education" [11]. This was true as Reen, a 12-year-old girl, said that after school she goes to the market and sells food in order to earn money so that she can help her mother and siblings. She wakes at 6am and walks to school. She said, "I feel tired and weak because it is a very long day for me. I do not have time to study because I have to work. Sometimes, I do not go to school because I am too tired to wake up in the morning. Sometimes my teacher beats me because I arrive late at school. Sometimes in the market people harass me and shout at me and I do not know what to do". This shows that Reen physically affected by work. She is too young to work and go to school.

Other children are engaged in hazardous jobs such as Thomas who is 16 years and work in a bakery at night. Several times, he said that he burned his hands from the heat of the oven, he coughs always and he feels that his respiratory system is not well. He did not go to the doctor because it is expensive and he needs the money to support his family. His night shift made him physically weak and unable to perform in the mornings. From the case studies above, children suffered from psychological or mental wellbeing but there is limited research in this area. Researchers deliberate the physical and social consequences; however, 
mental health area is not been explored so much. Studies are lacking in Sudan regarding impact of child labor on mental health.

\section{Discussion}

The case studies, combined with literature research and interviews with the children, highlight the challenges that displaced children face in securing income and supporting themselves or their families.

Economic pressure on children to work is a problem that conflicts with education and health. Children find themselves struggling between continuing school and work and in most cases, the children stop school.

The influence that families exert on children to work can cause children to despise their parents and feel that they are not supportive, as the work atmosphere is harder and more dangerous for children. Reen mentioned she helps her mother and sibling by working and contributing financial support to the family. However, Reen might stop school and continue work to support her family. She is a source of income to her family. She will find that it will be difficult to combine work and education as she already mentioned that she arrives late at school.

Violence frequently used on children at the workplace. Reen mentioned that because of arriving late at school she was beaten. Children were frequently beaten for such reasons as disobedience, unfinished work, or laziness. Reen mentioned that she get harassed at work and shout at her in the market. This can affect the child's development, personality, and behavior. It is likely to lead to lack of confidence and unhealthy thinking, and even to mental disorders.

Sexual harassment is one of the greatest problems facing children, particularly girls as Reen mentioned. There are cases of children assaulted sexually by their employers, fellow workers and customers. This can have an impact both psychologically and physically. Moreover, it exposes them to sexual transmitted diseases, including AIDS, or unwanted pregnancies. The problem is that girls do not report such incidents.

Physical weakness and physical ill health are two of the results of combining work and education. In the case of Reen and Thomas, the children complain of exhaustion and fatigue. This is likely to affect their health contributing to serious problems such as malnutrition. Thomas mentioned that he burned himself several time at the bakery. This in itself can affect his physical health and his continuation in education. The fatigue and exhaustion might affect his attendance at school and performance. A student need to have slept enough and physically fit in order to perform well at school. However, in the case of both Reen and Thomas, the situation is worse and they complain from physical problems.

Children are likely to lose interest in education if they work. They can become discouraged about going to school. They are cheap laborers, sexually harassed, physically, psychologically and mentally affected.

\section{Conclusion and Recommendations}

This paper has presented income-generating activities among the displaced 
children, why children are involved in labor and explained few of the challenges that children experience while working. The paper explained the need for children to work in order to support themselves and their families. The paper explained that because of the poor conditions in the camps, the lack of services and support from the government, the children had to find strategies to survive and generate income. Nevertheless, these strategies have an impact on the health of the children. This is in violation to their rights.

Therefore, I would recommend the provision food, shelter, health and education by the state for the displaced people in the camps. This might not lead the children to be engaged in labor. If the state had a system for displaced people helping the families to generate income, the children might not need to work to support themselves and their families. The enhancement and monitoring of child labor laws by the governmental and non-governmental organizations concerned and the provision of penalties for infringement might decrease the incidents of child labor in Sudan. The state and non-governmental organizations need to co-operate in combating the phenomena of child labor, facilitating education of displaced children and to make primary education free and accessible to all displaced children. This would probably lessen the dropout rate and the incidence of child labor. This is because, as mentioned earlier, the children need to pay for their school expenses. Community awareness of the importance of education to their children and their families especially girls education, needs to be raised. State and organizations intervention in promoting education and health is important, particularly in relation to child labor. An increase in budget for education from the state is likely to lower the dropout rate from schools in Sudan.

\section{Disclaimer}

The paper reflects the personal opinion of the author and is not necessarily endorsed by the Doha International Family Institute. This paper was presented at the 2nd annual conference on Family Research and Policy: The Impact of Wars and conflicts on Arab Families organized by Doha International Family Institute.

\section{References}

[1] World Population Review (2014) Sudan Population 2014. http://worldpopulationreview.com/countries/sudan-population/

[2] World Fact Book (2015) Sudan. The World Fact Book. Central Intelligence Agency and Director of Central Intelligence.

https://www.cia.gov/library/publications/the-world-factbook/geos/su.html

[3] IDMC (2010) Sudan. Rising Inter-Tribal Violence in the South and Renewed Clashes in Darfur Cause New Waves of Displacement.

http://www.internal-displacement.org/assets/library/Africa/Sudan/pdf/sudan-overvi ew-may2010.pdf

[4] Lyytinen, E (2009) A Tale of three cities: Internal Displacement, Urbanization and 
Humanitarian Action in Abidjan, Khartoum and Mogadishu. UNHCR. http://reliefweb.int/sites/reliefweb.int/files/resources/7D03CEEEF0FD150A492575 DB00210A0D-Full_Report.pdf

[5] UNOCHA (2004) Guiding Principles on Internal Displacement. http://www.unhcr.org/protection/idps/43ce1cff2/guiding-principles-internal-displa cement.html

[6] Abdelmoneium, A. (2005) Challenges Facing Children in Education and Labor: A Case Study of Displaced Children in Khartoum-Sudan. Ahfad Journal for Women's Studies, 22, 64-76.

[7] Labour Office (1997) Labour Law for the Year 1997. Khartoum: Sudan (translated unpublished report).

[8] Abdelmoneium, A. (2008) Non-Governmental Organizations and the Rights of Displaced Children in Sudan. PhD Dissertation, Institute of Gender Studies

[9] Norwegian Council for Africa (2012) Darfurian IDPs in Khartoum: A Painful Narrative of a Struggle for Survival. 29 February 2012.

[10] Nieuwenhuys, O. (1994) Children's Lifeworlds, Gender, Welfare and Labour in the Developing World. Routledge, London.

[11] Srivastave, K. (2011) Child Labor Issues and Challenges. Industrial Psychiatry Journal, 20, 1-3. https://doi.org/10.4103/0972-6748.98406

Submit or recommend next manuscript to SCIRP and we will provide best service for you:

Accepting pre-submission inquiries through Email, Facebook, LinkedIn, Twitter, etc. A wide selection of journals (inclusive of 9 subjects, more than 200 journals)

Providing 24-hour high-quality service

User-friendly online submission system

Fair and swift peer-review system

Efficient typesetting and proofreading procedure

Display of the result of downloads and visits, as well as the number of cited articles

Maximum dissemination of your research work

Submit your manuscript at: http://papersubmission.scirp.org/

Or contact jss@scirp.org 